\title{
OBLIGATIONS ERGA OMNES - JUS COGENS IN STATU NASCENDI? A THEORY INSPIRED BY THE NATURE OF INTERNATIONAL LAW
}

\begin{abstract}
This paper is a follow-up to a debate on the book "The Nature of International Law" by Miodrag A. Jovanović. First, the approach towards erga omnes obligations adopted in the book is analyzed, after which a different perspective towards the concept is offered. The curious case of erga omnes obligations can be summed up by stating that there has hardly been more elucidated concept in international law but with so little clarification achieved. With the aim of shedding more light on this conundrum, the concept is compared to others of a similar nature, primarily jus cogens norms, only to identify that erga omnes obligations could be defined as jus cogens in statu nascendi. Respectively, it is argued that according to the current state of affairs in the international community, the International Court of Justice is an instance of last resort when distinguishing between jus cogens norms and obligations erga omnes. Finally, the view concerning the three-layered nature of the international legal hierarchy is accepted, with jus cogens norms having the highest rank, followed by erga omnes obligations and with the jus dispositivum of international law in third place.
\end{abstract}

Key words: erga omnes obligations, jus cogens, peremptory norms of international law, International Court of Justice, International Law Commission.

\section{On The Nature of International LaW -}

\section{A Book by Miodrag A. Jovanović}

It is high time that discussions about The Nature of International Law started. The book was published by Cambridge University Press in 2019, but due to the extraordinary circumstances of 2020, a symposium on the publication was organized at the Faculty of Law University of Belgrade only in June 2021. This predominantly gathered scholars specialized in international law, which indicates that the author succeeded in attaining the

PhD candidate, University of Belgrade Faculty of Law; e-mail: ana.zdravkovic@ius. bg.ac.rs 
attention of an audience outside the realm of pure jurisprudence. This paper is one of the follow-ups to the debate that took place at the symposium.

The Nature of International Law is, in a nutshell, a treatise on the typical features of what is called the international legal order, namely normativity, institutionalization, coercive guaranteeing and justice-aptness. Written in a comprehensible and appealing style, which is arguably not always typical for pieces by legal philosophers, in a masterly way the book tackles the issues of the development of the theory of international law, a hierarchy of formal sources of international legal norms, institutionalization, fragmentation and the judicialization of international legal order, to name just a few. An especially compelling point is made at the very end, regarding the (ir)relevance of legal uncertainty and it is particularly worth mentioning that there is a graspable and conclusive comparison between two branches of public law: constitutional and international law. The book will most certainly serve multiple functions. Not only does it have the substantial capacity to spark academic debate on the various matters it elucidates, but as a rather compendious and interdisciplinary work, it should also be beneficial to every young scholar specializing in either legal theory or international law.

Naturally, taking into account the enormous width and reach of the book's subject, together with the restraints imposed by the limited number of pages which are inherent in every monograph of this kind, it can be expected that there are certain aspects of the subject that were not sufficiently regarded by the author, and which certainly deserved more in-depth analysis. One of these issues, upon which the book only briefly touches, is the concept of erga omnes obligations, a concept that has been with us for over half a century and that almost any lawyer would recognize to a certain extent but hardly know how exactly to define. The aim of this paper is to contribute to the demystification of this blurred concept of international legal norms and, by offering an unconventional explanation of the notion in hand, to serve as a prompter for achieving clarity and sharper distinction between different categories of international legal norms. After all, it is in the Nature of International Law that admittedly "a special sort of uncertainty concerns determining which normative content has the formal quality of a jus cogens norm and/or an erga omnes obligation". ${ }^{1}$ Before any normative content can be filled into these categories, they must somehow receive even the contours of defined concepts. Even more, if the author's own remark on achieving "the highest possible level of uncertainty absorption"2 should be followed.

1 Jovanović, M. A., 2019, The Nature of International Law, Cambridge, Cambridge University Press, p. 230.

2

Ibid. 


\section{ERga OmNes Obligations in \\ THE NATURE of INTERNATIONAL LAW}

A brief exposé in the book dedicated to erga omnes obligations is placed within the chapter "International Law as a Normative Order" in the section that epistemologically analyzes how to ascertain valid international legal norms, as well as how to ascertain norms stemming from different classes of general international legal rules, such as jus cogens or erga omnes obligations. Firstly, it is reminded that the concept of erga omnes obligations is the invention of the International Court of Justice (hereinafter: ICJ), as pronounced in the well-known obiter dictum of the Barcelona Traction case, where the Court stated that "an essential distinction should be drawn between the obligations of a State towards the international community as a whole, and those arising vis-à-vis another State [...] By their very nature the former are the concern of all States. In view of the importance of the rights involved, all States can be held to have a legal interest in their protection; they are obligations erga omnes." 3 In addition, the Court provided examples of such obligations in contemporary international law, namely the prohibition of aggression, the prohibition of genocide, obligations correlative to the basic human rights, including protection from slavery and racial discrimination. ${ }^{4}$ After more than two decades, the Court added the right to self-determination to the list of erga omnes norms, explaining that it is not only an integral part of the UN Charter, but also recognized in the jurisprudence of the Court, and emphasizing that it is among fundamental principles of contemporary international law. ${ }^{5}$

Following the introductory part regarding ICJ's development of the concept, an important finding is stated in the book. That is, "all the mentioned obligations derive from norms of jus cogens", hence the remainder

3 ICJ, Barcelona Traction, Light and Power Company, Limited (Belgium v. Spain), Judgment of 5 February 1970, ICJ Reports 1970, p. 33, para. 33.

4 Ibid, para. 34. Apparently, this concept differs from obligations stemming from treaties that produce erga omnes effect because of their nature, such as those regulating international boundaries, freedom of navigation in international straits or those establishing neutralized or demilitarized zones, see more in Linderfalk, U., 2011, International Legal Hierarchy Revisited - The Status of Obligations Erga Omnes, Nordic Journal of International Law, Vol. 23, p. 5. Also, both the doctrine and the ICJ recognize the concept of obligations "erga omnes partes", which are obligations stemming from multilateral treaties and which are owed only to other State parties of that treaty, hence any State party may demand the responsibility of another, ICJ, Questions relating to the Obligation to Prosecute or Extradite (Belgium v. Senegal), Judgment of 20 July 2012, ICJ Reports 2012 (II), p. 450, para. 69.

5 ICJ, East Timor (Portugal v. Australia), Judgment of 30 June 1995, ICJ Reports 1995, p. 102, para. 29. 
of the author's attention is concentrated on "the analysis of the relationship between the two concepts". ${ }^{\text {This }}$ statement will also serve as the starting thesis for the analysis that will follow in the second part of this paper. Before that, let us skim over the author's main points.

To start with, it is accepted that any inquiry into the matter must be two-folded; the first stage revolves around identification of norms designated with some higher legal rank, while the second stage is based on clarification of the special legal consequences arising out of breaches of such "superior" norms. ${ }^{7}$ With regard to the first stage, it is emphasized that there is no universal agreement about whether erga omnes obligations have any kind of superior status at all, in the same manner as jus cogens norms obviously have. ${ }^{8}$ Even though the doctrine widely attributes them with this higher normative power, ${ }^{9}$ the International Law Commission (hereinafter: ILC) took the opposite view, stating that erga omnes obligations imply no superiority over other international legal norms, but only determine the scope of application of the relevant law as well as the ensuing procedural consequences. ${ }^{10}$ When it comes to the legal consequences, it is accurately noted that jus cogens norms make conflicting treaties void, while erga omnes obligations entitle States that are not directly affected by an international wrongful act (that is, a breach of such a norm) to invoke the responsibility of the violator, since those obligations are owed to all members of the international community. ${ }^{11}$ Then, several common elements of erga omnes obligations are determined, although it is admitted that they are all merely descriptive. Thus, they may only provide a useful framework for the inquest of prospective candidates for such international legal status, but cannot be considered to be decisive criteria themselves. ${ }^{12}$ Specifically, erga omnes norms are all narrowly defined obligations, negative obligations (prohibitions), strict obligations (duties), they all stem

\section{Jovanović, M. A., 2019, p. 120.}

$7 \quad$ Ibid. See also, Tomuschat, C., Reconceptualizing the Debate on Jus Cogens and Obligations Erga Omnes - Concluding Observations, in: Tomuschat, C., Thouvenin, J., (eds.), 2006, The Fundamental Rules of the International Legal Order, Leiden, Martinus Nijhoff Publishers, pp. 429-430.

$8 \quad$ Ibid.

9 Author refers to Tomuschat (note 7) and Kadelbach, see Kadelbach, S., Jus Cogens, Obligations Erga Omnes and other Rules - The Identification of Fundamental Norms, in: Tomuschat, C., Thouvenin, J., (eds.), 2006, The Fundamental Rules of the International Legal Order, Leiden, Martinus Niijhoff Publishers, p. 26.

10 Jovanović, M. A., 2019, p. 121, citing International Law Commission, Fragmentation of International Law: Difficulties arising from the Diversification and Expansion of International Law, A/CN.4/L.682 (13 April 2006), p. 193, para. 380.

11 Jovanović, M. A., 2019, p. 120. See also, Kadelbach, S., 2006, p. 26.

12 Ibid., p. 122. 
from jus cogens norms and they are all instrumental for the current international community which is committed to safeguarding world peace as well as human rights. ${ }^{13}$ This last feature is characterized as a substantial one, since it indicates that these obligations protect basic moral values and represent, to quote the ICJ, "the concern of all States", so this element could be pivotal in the process of identification of erga omnes obligations. ${ }^{14}$

Finally, to the inevitable question of who should ascertain whether a particular norm has such a status, the book recalls the view of Cassese on the same question regarding jus cogens norms, according to whom the task should be entrusted to international judicial courts and tribunals. ${ }^{15}$ In conclusion, a general point is made, namely that it is ultimately upon law-applying institutions to determine whether a content-specific rule passes the threshold criteria of the given order so as to count as a valid legal rule. ${ }^{16}$

\section{Erga Omnes Obligations - The Spitting Image of Jus Cogens?}

At the outset of the analysis, it is important to elaborate the book's finding that "all the mentioned obligations derive from norms of jus cogens". To do that, the last report of the ILC regarding peremptory (jus cogens) norms of international law must be referred to. ${ }^{17}$ In the pages of the report, an illustrative list of norms that have acquired the jus cogens status is provided; it contains: "the prohibition of aggression, the prohibition of genocide, the prohibition of slavery, the prohibition of apartheid and racial discrimination, the prohibition of crimes against humanity, the prohibition of torture, the right to self-determination and the basic rules of international humanitarian law". ${ }^{18}$ Clearly, enumerated norms almost completely overlap with the erga omnes obligations catalogue that the ICJ established in the abovementioned judgment. ${ }^{19}$ Moreover, it is rather

13 Ibid, pp. 121-122. Author relies on the findings of Ragazzi, M., 1997, The Concept of International Obligations Erga Omnes, Oxford, Oxford Clarendon Press, pp. 132-134.

14 Ibid., p. 122.

15 Ibid., p. 123, citing Cassese, A., For an Enhanced Role of Jus Cogens, in: Cassese, A., (ed.), 2012, Realizing Utopia - The Future of International Law, Oxford, Oxford University Press, p. 164.

16 Ibid.

17 International Law Commission, Fourth Report on Peremptory Norms of General International Law (Jus Cogens) by Dire Tladi, Special Rapporteur, A/CN.4/727 (31 January 2019).

18 Ibid., p. 26, para. 60.

19 According to the ILC, "examples provided by the Court (of erga omens obligations, A. Z.) are all part of the Commission's list of examples of norms of jus cogens", ibid., p. 42, para. 93. 
interesting to examine the ILC's argumentation for including these particular norms in the exemplifying jus cogens list. When it comes to the status of the prohibition of aggression, the prohibition of torture and the prohibition of genocide, it is emphasized that the ICJ unambiguously recognized them as norms of jus cogens. ${ }^{20}$ Although further reference is made to the case-law of other international courts, quasi-judicial bodies and national courts, the previous work of the ILC, commentaries and stands of various States and the doctrine, one might gain the impression that all of this was somehow needless, after the thronal reference to the ICJ. Things are just slightly different in relation to the rest of the identified norms. For instance, it is stated that even though the ICJ has not expressly proclaimed the prohibition of apartheid and racial discrimination to be jus cogens, it did qualify them as erga omnes obligations. ${ }^{21}$ Concerning jus cogens status of the prohibition of slavery, it is similarly concluded that it was indirectly recognized, once the Court acknowledged erga omnes character of the norm. ${ }^{22}$ In like manner, primary evidence of peremptory status of the right to self-determination was found in its inclusion into the list of norms with erga omnes quality; ${ }^{23}$ and finally, the same was emphasized in regard to the rules of international humanitarian $\mathrm{law}^{24}$. So, it is safe to conclude that, at least as long as the ILC is concerned, the jus cogens status emanates primarily from the erga omnes nature of the norm.

Yet, the stance of the ILC was not always in line with this conclusion. Back in 2006, the ILC took the view that, albeit the norms that the ICJ had described as obligations erga omnes may also be related to the jus cogens, the aim of the Court was neither to highlight their non-derogable nor substantial nature, but rather to indicate the existence of rules that once violated induce general standing to make claims. ${ }^{25}$ Therefore, erga omnes norms were characterized as obligations that concern secondary, not primary rules and as norms with certain procedural features, amounting to the right of any State to appeal against their breach. ${ }^{26}$

This kind of reasoning is motivated by the same argumentation underlying the doctrinal consideration that erga omnes obligations are the concept of State responsibility. ${ }^{27}$ By way of explanation, in the Articles on Responsibility of States for Internationally Wrongful Acts (hereinafter:

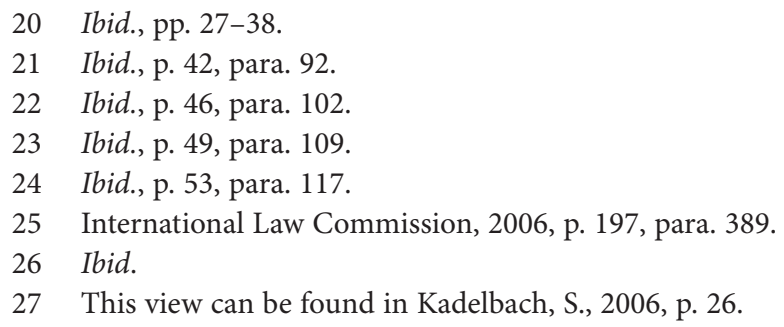


ARSIWA) a distinction was drawn between breaches of obligations which are owed to the international community as a whole, breaches of obligations arising under a peremptory norm, and serious breaches of obligations under peremptory norms. ${ }^{28}$ Obviously, ARSIWA does not mention the term erga omnes and it further complicates and confuses these insufficiently clear normative relations. ${ }^{29} \mathrm{Be}$ that as it may, every infringement of obligations vis-à-vis the international community empowers third States to claim responsibility of the violator and request cessation of the breach, as well as assurances and guarantees of non-repetition and reparations for the injury caused to the respective beneficiaries of such obligation. ${ }^{30}$

On the other hand, legal effects of breaching peremptory norms are more complex. In that case, circumstances precluding wrongfulness, i.e., "consent, self-defence, countermeasures, force majeure, distress, and necessity" cannot serve as an excuse for violations, ${ }^{31}$ which is probably the result of their inalienable character and the commonly accepted view that they must be respected at all times.

Finally, when it comes to serious breaches of obligations under peremptory norms, apart from the legal implications already stipulated by ARSIWA with regard to other "non-serious" breaches and those entailed under international law, additional outcomes are determined. To be specific, "states should cooperate to bring to an end, through lawful means, any serious breach, they must not recognize as lawful a situation created by a serious breach, nor render aid or assistance in maintaining that situation".32

Therefore, it is obvious that jus cogens is not a notion concerning only the quality of the normative content, whereas erga omnes obligations target the scope of the cogens rule and represents its consequence. ${ }^{33}$ From

28 International Law Commission, Draft Articles on Responsibility of States for Internationally Wrongful Acts, A/56/10 (November 2001), Art. 40, 42 and 48. Serious breach replaced the disputed notion of international crime, and it is defined as a gross or systematic failure by the responsible State to fulfil its obligation.

29 Similar opinion can be found in Kadelbach, S., 2006, pp. 36-37.

30 International Law Commission, 2001, Arts. 48 and 54, referring to the general principles laid down in the Chapter 1, see also Arts. 28-31. Article 54 is described as a saving clause, since it passes on the question of legality of countermeasures undertaken by third States as a response to the breach of obligations towards international community, to the subsequent development of international law, see International Law Commission, Draft articles on Responsibility of States for Internationally Wrongful Acts, with Commentaries, Yearbook of the International Law Commission, 2001, Vol. II, Part Two, p. 139.

31 Ibid, Art. 26.

32 Ibid., Art. 41.

33 Pellet, A., Conclusions, in: Tomuschat, C., Thouvenin, J., (eds.), 2006, The Fundamental Rules of the International Legal Order, Leiden, Martinus Nijhoff Publishers, p. 
the ARSIWA point of view, jus cogens norms seem to be an independent category, whose breach is followed by a spate of various consequences, depending on the severity of a particular violation.

Then again, one additional reference needs to be made at this point. In one of its advisory opinions, the ICJ qualified construction of the wall in the occupied Palestinian territory as a violation of erga omnes obligations. ${ }^{34}$ Furthermore, the Court considered that, due to the nature and significance of the rights and obligations in hand, all States were obliged not to recognize the illegal situation which is a result of the breach of relevant obligation, but also to refrain from providing aid or assistance in maintaining the created situation, as well as to make sure that any illegal consequence arising from the such activity would be terminated. ${ }^{35}$ To rephrase it, the ICJ applied the consequences of serious breaches of jus cogens norms to the breach of duties, it had previously described as erga omnes obligations, thus merged the two concepts together. As if things were not perplexing enough, the ILC has used this confusing reasoning of the ICJ as an additional argument for justifying its qualification of the right to self-determination as a jus cogens norm. ${ }^{36}$ Plainly, all of these inconsistent deductions and sometimes vicious circles are a result of insufficiently defined and elucidated concepts.

Lastly, the manner in which the ICJ had explained the erga omnes obligations, in particular their effect of giving rise to the legal interest of all States to claim compliance with them, may lead to the assumption that any State will have the right to seise the Court when such obligations are violated. Given that the ICJ is the main adjudicative organ of the UN, together with the fact that peaceful settlement of international disputes is one of the pillars of public international law, it would arguably be expected that this organ would find an appropriate way to react in case of infringement of rules it itself had characterized as most fundamental and that it would allow third States, that are not directly affected by the unlawful act, to bring disputes in these exceptional situations. Additional argument for following this line of reasoning is the perspective of the victims of such violations, who oftentimes amount to either politically fragile and incapacitated States or even the population of the responsible State itself. With that in mind, it can hardly be envisaged that those imperiled

418. See also, Bassiouni, M. C., 1996, International Crimes, International crimes: jus cogens and obligatio erga omnes, Law and Contemporary Problems, Vol. 59, p. 63.

34 ICJ, Legal Consequences of the Construction of a Wall in the Occupied Palestinian Territory, Advisory Opinion of 9 July 2004, ICJ Reports 2004, para. 155.

35 Ibid., para. 159.

36 International Law Commission, 2019, p. 49, para. 109. 
by the breaches of erga omnes norms would be capable of referring to the Court, which is the decisive point that led to the idea of allowing third States to bring these types of disputes before the Court. However, a major impediment here is the consensual jurisdiction of the Court. When confronted with this matter, the ICJ adopted a rather restrictive attitude, the same one it took regarding almost identical question of its jurisdiction in the event of jus cogens breaches. In respect of peremptory norms, the Court insisted that the concept cannot modify or displace the application of rules regulating the scope of its jurisdiction. ${ }^{37}$ The ICJ has adjudicative authority exclusively towards those States that have voluntarily agreed upon its jurisdiction and only to the extent that their consent allows. ${ }^{38}$ In the absence of the prescribed jurisdictional basis, such as the special agreement to submit the particular dispute to the Court, compromissory clause, declaration recognizing as compulsory the jurisdiction of the Court or forum prorogatum, this organ cannot assess the matter in hand, even if possible violation of erga omnes obligations is at stake. ${ }^{39}$ Apparently, additional common feature of both jus cogens norms and erga omnes obligations is that the ICJ may not respond to their infringement, since its hands are tied by rigid and outdated legal rules, which were laid down long before these normative categories were developed and accepted. The pressing need for amending these procedural rules will become apparent over time, if it already has not been the case. Nevertheless, it must be noted that certain progress regarding this matter can be identified in recent years. While ruling on the admissibility of certain claims, in cases where its jurisdiction was firmly based on relevant conventional provisions, the Court actually granted legal standing to States that had no traditionally understood „special interest" in the particular matter, but rather broader legal interest stemming from erga omnes (partes) character of the obligations in hand. ${ }^{40}$ By doing so, the Court ultimately departed from its highly criticized and disputable stance adopted in South West Africa decisions ${ }^{41}$ and showed willing for progressive development and alternation of old

37 ICJ, Jurisdictional Immunities of the State (Germany v. Italy), Judgment of 3 February 2012, ICJ Reports 2012, p. 46, para. 95. For a more broader study on peremptory norms and international judicial jurisdiction, see Orakhelashvili, A., 2006, Peremptory Norms in International Law, New York, Oxford University Press, pp. 490-508.

38 United Nations, Statute of the International Court of Justice, 18 April 1946, Article 36.

39 ICJ, East Timor (Portugal v. Australia), p. 102, para. 29.

40 ICJ, Questions relating to the Obligation to Prosecute or Extradite (Belgium v. Senegal), paras. 68-70; ICJ, Application of the Convention on the Prevention and Punishment of the Crime of Genocide (Gambia v. Myanmar), Order of 23 January 2020, paras. 41-42.

41 ICJ, South West Africa Cases (Ethiopia v. South Africa; Liberia v. South Africa), Second Phase, Judgment of 18 July 1966, ICJ Reports 1966, para. 15. 
concepts. Although these occurrences may be promising, the consensual nature of the ICJ's jurisdiction remains a considerable obstacle for full practical implementation of the erga omnes concept.

\section{Erga Omnes Obligations and Jus Cogens - If There Is A Difference, What IS The Difference?}

To become a jus cogens norm of general international law a norm must be accepted and recognized by the entire international community as a non-derogable one. ${ }^{42}$ Once it acquired that status, it cannot be modified unless a subsequent norm having the same character is introduced. ${ }^{43}$ Having regard to the fact that the concept was formally established via the international law of treaties, its primary function in public international law was to make conflicting treaties null and void. ${ }^{44}$ In the meantime, the term not only introduced the hierarchization of international legal order, but also became a common denominator for rules encompassing issues of the utmost priority for the international community ${ }^{45}$ As already illustrated in the previous section, international community is bound by special legal implications as well as unique set of obligations in the event of infringement of jus cogens norms. This is particularly true regarding serious breaches but let us also examine the consequences of "ordinary" breaches of jus cogens norms.

With that goal in mind, it must be clarified that these norms, as understood nowadays, are necessarily norms established under general international law; that is, norms that have a general scope of application, arising from either multilateral treaties or international customary law. ${ }^{46}$ This logically follows from their definition, which explicitly requires that such norms must be accepted and recognized by the whole international com-

42 United Nations, Vienna Convention on the Law of Treaties, Treaty Series, Vol. 1155, p. 331, (23 May 1969), Art. 53.

43 Ibid.

44 If the treaty conflicts with a peremptory norm of general international law at the time of its conclusion, it is void, ibid.

45 For more detailed analysis of the concept, see Jovanović, M. A., 2020, Jus Cogens: A Complex Case of Constitutional Reasoning in International Law, RphZ Rechtsphilosophie, Vol. 6, No. 3, pp. 249-262.

46 For more about groundlessness of regional jus cogens, see Zdravković, A., 2019, Finding the Core of International Law - Jus Cogens in the Work of International Law Commission, South Eastern Europe and the European Union - Legal Issues, Vol. 5, pp. 156-157. 
munity as legal rules that cannot be derogated, which concurrently implies that they must have previously been accepted and recognized as international legal rules. Accordingly, the effect of jus cogens norms is not bilateral in its nature, but rather erga omnes - meaning towards all. All the more so, because once the norm reaches the non-derogable status due to its vital importance, such a norm must be universally binding on all subjects of international law as they all have legitimate interest in its preservation and protection. ${ }^{47}$ As a result, an "ordinary" breach of a jus cogens norm can be understood as a breach of obligations $v i s-a-v i s$ the international community, consequently entitling every other State to request that the wrongdoer accepts responsibility and to demand cessation, assurances, guarantees of non-recurrence, and reparation for the injured State. Put differently, the consequences of breaching jus cogens norms completely cover consequences commonly ascribed to breaches of erga omnes obligations.

Following this finding, it becomes apparent that the two-stage analysis that Jovanović accepts in the book is not so useful, since the second stage referring to the special legal consequences following from violations cannot reveal whether the norm in hand is jus cogens or an obligation erga omnes.

Both peremptory norms and erga omnes obligations designate special types of legal commands which are hierarchically ranked above "ordinary" rules of international law. Although it was already mentioned that there were some doubts as to whether erga omnes obligations were indeed of a higher status then others, not much support can be found for that sort of skepticism in either doctrine or case-law. While scholars describe them as obligations of a higher normative value, ${ }^{48}$ a subcategory of international constitutional law, ${ }^{49}$ or as protecting values of heightened importance, ${ }^{50}$ the ICJ associated erga omnes character of obligations with fundamental and intransgressible nature of certain principles, that were even described as basic considerations of humanity. ${ }^{51}$ It emphasized that all States must

47 Wet, E. de, 2006, The International Constitutional Order, International and Comparative Law Quarterly, Vol. 55, No. 1, p. 61. See also, Wet, E. de, Jus Cogens and Erga Omnes, in: Shelton, D., (ed.), 2013, Oxford Handbook on Human Rights, Oxford, Oxford University Press, p. 15.

48 Hoogh, A. J. J. de, 1991, The Relationship Between Jus Cogens, Obligations Erga Omnes, and International Crimes: Peremptory Norms in Perspective, Austrian Journal of Public International Law, Vol. 41, p. 192. See also, Wet, E. de, 2006, p. 62.

49 Fassbender, B., 1998, The United Nations Charter as Constitution of the International Community, Columbia Journal of Transnational Law, Vol. 36, No. 3, p. 591.

50 Tams, C., 2005, Enforcing Obligations Erga Omnes in International Law, New York, Cambridge University Press, p. 310.

51 ICJ, Legality of the Threat or Use of Nuclear Weapons, Advisory opinion of 8 July 1996, ICJ Reports 1996, p. 257, para. 79. 
adhere to those obligations, regardless of whether they are parties to the relevant international treaties that contain them. ${ }^{52}$

Therefore, the only difference between these two normative categories is the unique non-derogability trait of jus cogens. This is the rationale for defining erga omnes obligations as jus cogens in statu nascendi. They truly represent narrowly defined negative duties, but they do not "stem from jus cogens". On the contrary, they aspire to reach the highest normative status of jus cogens; for that they have already fulfilled the requirement to be universally applicable norms, hence can be regarded as part of general international law, they seek to protect the common interests of all human beings, but they are simply not yet acknowledged as norms from which no derogation is permitted. In accordance with this proposition is the belief of some scholars that the international legal hierarchy has a layered nature, comprising jus cogens as the superior category, erga omnes obligations that have developed into norms of customary law, but still not jus cogens norms, and lastly, other dispositive (non-peremptory) norms of international law. ${ }^{53}$

Finally, it is necessary to untangle the mystery of who will identify whether a particular norm is the obligation erga omnes or jus cogens. This can also be rephrased as to who should identify whether the norm is non-derogable one. Although in principle the answer should be straightforward and should be the international community, i.e., the totality of subjects of public international law, serving in the capacity of its main legislator, at this stage of the development of the international legal order that does not seem to be a feasible solution. On the one end of the spectrum are States which are reluctant to utilize these concepts in their relations and argumentations due to political considerations, lack of knowledge, or simple disinterest, while on the other there are those prone to the misinterpretation of various legal instruments with the aim of promoting their own interests. ${ }^{54}$ Thus, Jovanovićs statement that this determination task should be entrusted to the law-applying institutions must be accepted. With respect to the facts presented so far, along with the present circumstances in the international community, it seems reasonable to concretize that statement by indicating that the ICJ is actually the one ascertaining

\section{Ibid.}

53 Linderfalk, U., 2011, p. 19. Similar statement that norms expressing obligations erga omnes form a second layer of the international value system, which is positioned under peremptory norms, in Wet, E. de, 2006, p. 62.

54 Most obvious example would be the misuse of the peremptory right of armed self-defence, for more see Green, J. A., 2009, The International Court of Justice and Self-Defence in International Law, Oxford, Hart Publishing, pp. 111-147. 
the non-derogable character of norms. ${ }^{55}$ Not only has the Court come forward with a new normative category in the first place, but it also provided itself as an instance of last resort when distinguishing between jus cogens norms and obligations erga omnes. Hence, this finding should be understood as one merely stemming from the reality, rather than any kind of suggestion or rave.

\section{From The Nature of International LaW to the Nature of ERga Omnes Obligations}

Notwithstanding the fact that most of the considerations regarding the erga omnes obligations from The Nature of International Law were found to be untenable throughout the analysis, this paper was mainly inspired by the aforementioned book. Furthermore, it can hardly be denied that the concept of erga omnes obligations is not illuminated enough, which is apparent from countless different theories about it and its usage in various contexts and connotations. As an illustration, the Barcelona Traction judgment was even cited as a reference to jus cogens, ${ }^{56}$ indicating that terms are sometimes used interchangeably as synonyms. This view, although it may seem appealing, cannot be accepted, because if the Court had in mind jus cogens, it would have resorted to that concept.

The inquiry started from scrutinizing the statement that all determined obligations erga omnes derive from norms of jus cogens, bearing in mind that the distinction between these normative concepts is not as clearcut as it may appear on the face of it. It was shown that all obligations which the ICJ has qualified as erga omnes found their place in the illustrative list of jus cogens norms, while the ILC used their erga omnes character as a first argument for justifying the assigned peremptory status. Furthermore, it was revealed that both concepts encompass core ethical values of the international community, both produce erga omnes effects, and their breaches lead to rather similar legal consequences, hence that they cannot be differentiated based on these criteria. Another detected similarity amounts to the inability of third States to bring disputes before the ICJ in

55 For the opinion that the confirmation of the ICJ is the final requirement for the norm to become jus cogens, see Zdravković, A., Međunarodni sud pravde - vladalac ili mislilac?, in: Jovanović, M. A., Zdravković, A., (eds.), 2020, Sudstvo kao vlast, Beograd, Centar za pravosudna istraživanja, p. 169.

56 Elias, T. O., 1974, The Modern Law of Treaties, New York, Oceana Publications, p. 185. Truth be told, the ICJ has a tradition of avoiding the phrase jus cogens, which only further provokes speculations on the clash between the two concepts, Kadelbach, S., p. 36. 
case of infringement of either jus cogens or erga omnes obligations, due to restrictive and inappropriate procedural rules regarding its consensual jurisdiction. These concepts, thus, widely coincide with each other but are not identical. The distinctive trait of jus cogens norms is their non-derogable nature, which erga omnes obligations do not possess. For this reason, all jus cogens norms are erga omnes at the same time, but not the other way around, or in other words, not all erga omnes obligations have attained the cogens status. ${ }^{57}$ The proposed explication following from these findings is that erga omnes obligations are jus cogens in statu nascendi. Should certain erga omnes obligations once become worthy of entering jus cogens realm, it is the ICJ that will ultimately ascertain the matter. Accordingly, three-layered nature of the international legal hierarchy is accepted, with jus cogens norms having the highest rank, followed by erga omnes obligations and with the jus dispositivum of international law in third place.

After all, it must be appreciated that since the Barcelona Traction case, the Court has, in its own peculiar manner, outgrown the rigid positivistic and consent-based approach to the international law and paved the way for further development of a more coherent system of norms which will be regarded as a guardian of the common goods of the world. One of the pivotal features of the process of hierarchization and constitutionalization of international legal order is reaffirmation of the role of international law in protecting and preserving core ethical values of the international community.

On a final note, the objective of The Nature of International Law was not and could not be to solve each and every controversy of international law. Hence, this paper is an attempt not only to complement the wider debate of the issues tackled in the book, but also to serve as an incentive for the author to further contemplate various unresolved international legal matters and to continue with his unique contribution to the philosophy of international law. The Nature of International Law is certainly a much-needed call for the revival of the discipline.

\section{BIBLIOGRAPHY}

1. Bassiouni, M. C., 1996, International crimes: jus cogens and obligatio erga omnes, Law and Contemporary Problems, Vol. 59.

2. Elias, T. O., 1974, The Modern Law of Treaties, New York, Oceana Publications.

3. Fassbender, B., 1998, The United Nations Charter as Constitution of the International Community, Columbia Journal of Transnational Law, Vol. 36, No. 3.

4. Green, J. A., 2009, The International Court of Justice and Self-Defence in International Law, Oxford, Hart Publishing.

57 Wet, E. de, 2013, p. 15. 
5. Hoogh, A. J. J. de, 1991, The Relationship Between Jus Cogens, Obligations Erga Omnes, and International Crimes: Peremptory Norms in Perspective, Austrian Journal of Public International Law, Vol. 41.

6. Jovanović, M. A., 2019, The Nature of International Law, Cambridge, Cambridge University Press.

7. Jovanović, M. A., 2020, Jus Cogens: A Complex Case of Constitutional Reasoning in International Law, RphZ Rechtsphilosophie, Vol. 6, No. 3.

8. Kadelbach, S., Jus Cogens, Obligations Erga Omnes and other Rules - The Identification of Fundamental Norms, in: Tomuschat, C., Thouvenin, J., (eds.), 2006, The Fundamental Rules of the International Legal Order, Leiden, Martinus Nijhoff Publishers.

9. Linderfalk, U., 2011, International Legal Hierarchy Revisited - The Status of Obligations Erga Omnes, Nordic Journal of International Law, Vol. 23.

10. Orakhelashvili, A., 2006, Peremptory Norms in International Law, New York, Oxford University Press.

11. Pellet, A., Conclusions, in: Tomuschat, C., Thouvenin, J., (eds.), 2006, The Fundamental Rules of the International Legal Order, Leiden, Martinus Nijhoff Publishers.

12. Tams, C., 2005, Enforcing Obligations Erga Omnes in International Law, New York, Cambridge University Press

13. Tomuschat, C., Reconceptualizing the Debate on Jus Cogens and Obligations Erga Omnes - Concluding Observations, in: Tomuschat, C., Thouvenin, J., (eds.), 2006, The Fundamental Rules of the International Legal Order, Leiden, Martinus Nijhoff Publishers.

14. Wet, E. de, 2006, The International Constitutional Order, International and Comparative Law Quarterly, Vol. 55, No. 1.

15. Wet, E. de, Jus Cogens and Erga Omnes, in: Shelton D., (ed.), 2013, Oxford Handbook on Human Rights, Oxford, Oxford University Press.

16. Zdravković, A., 2019, Finding the Core of International Law - Jus Cogens in the Work of International Law Commission, South Eastern Europe and the European Union - Legal Issues, Vol. 5, pp. 156-157.

17. Zdravković, A., Međunarodni sud pravde - vladalac ili mislilac?, in: Jovanović, M. A., Zdravković, A., (eds.), 2020, Sudstvo kao vlast, Beograd, Centar za pravosudna istraživanja.

\section{LEgAL ACTS}

1. United Nations, Vienna Convention on the Law of Treaties, Treaty Series, Vol. 1155, p. 331 (23 May 1969).

\section{Case LaW}

1. ICJ, Application of the Convention on the Prevention and Punishment of the Crime of Genocide (Gambia v. Myanmar), Order of 23 January 2020.

2. ICJ, Barcelona Traction, Light and Power Company, Limited (Belgium v. Spain), Judgment of 5 February 1970, ICJ Reports 1970. 
3. ICJ, East Timor (Portugal v. Australia), Judgment of 30 June 1995, ICJ Reports 1995.

4. ICJ, Jurisdictional Immunities of the State (Germany v. Italy), Judgment of 3 February 2012, ICJ Reports 2012.

5. ICJ, Legal Consequences of the Construction of a Wall in the Occupied Palestinian Territory, Advisory Opinion of 9 July 2004, ICJ Reports 2004.

6. ICJ, Legality of the Threat or Use of Nuclear Weapons, Advisory opinion of 8 July 1996, ICJ Reports 1996.

7. ICJ, Questions relating to the Obligation to Prosecute or Extradite (Belgium v. Senegal), Judgment of 20 July 2012, ICJ Reports 2012 (II).

8. ICJ, South West Africa Cases (Ethiopia v. South Africa; Liberia v. South Africa), Second Phase, Judgment of 18 July 1966, ICJ Reports 1966.

\title{
OTher Sources
}

1. International Law Commission, Draft Articles on Responsibility of States for Internationally Wrongful Acts, A/56/10 (November 2001).

2. International Law Commission, Draft Articles on Responsibility of States for Internationally Wrongful Acts, with Commentaries, 2001, Yearbook of the International Law Commission, Vol. II, Part Two.

3. International Law Commission, Fourth Report on Peremptory Norms of General International Law (Jus Cogens) by Dire Tladi, Special Rapporteur, A/CN.4/727 (31 January 2019).

4. International Law Commission, Fragmentation of International Law: Difficulties arising from the Diversification and Expansion of International Law, A/CN.4/L.682 (13 April 2006).

\section{OBAVEZE ERGA OMNES - JUS COGENS U NASTAJANJU? ANALIZA INSPIRISANA KNJIGOM THE NATURE OF INTERNATIONAL LAW}

\author{
Ana Zdravković
}

\section{APSTRAKT}

Rad predstavlja nastavak diskusije o knjizi Miodraga A. Jovanovića The Nature of International Law, sa akcentom na koncept erga omnes obaveza. U tekstu je najpre predstavljen pristup obavezama erga omnes prihvaćen od strane autora knjige, a nakon toga je ponuđen nešto drugačiji pogled na ovaj koncept. Erga omnes obaveze u međunarodnom pravu su karakteristične po tome što pripadaju malobrojnim temama o kojima se puno pisalo, a malo razjasnilo. Shodno tome, cilj rada nije da odgovori na svako sporno pitanje u vezi sa ovim konceptom, već da pokuša da ga 
dodatno rasvetli, pre svega kroz upoređivanje sa sličnim konceptima, a na prvom mestu jus cogens normama. Nakon prikaza i analize različitih relevantnih okolnosti i argumenata, utvrđeno je da se erga omnes obaveze mogu definisati kao jus cogens norme u nastajanju. U kontekstu pitanja ko je ovlašćen da odlučuje o tome da li bi konkretnu normu trebalo uvrstiti u jednu ili drugu kategoriju, u radu je zauzet stav da ta uloga trenutno pripada Međunarodnom sudu pravde, imajući u vidu aktuelne odnose i stanje unutar međunarodne zajednice. Naposletku, u radu je prihvaćena teza da se normativna hijerarhija međunarodnopravnog poretka sastoji od tri nivoa, pri čemu jus cogens norme zauzimaju najviše mesto, dok se ispod njih nalaze erga omnes obaveze, a potom sve ostale dispozitivne norme međunarodnog prava.

Ključne reči: erga omnes obaveze, jus cogens, peremptorne norme međunarodnog prava, Međunarodni sud pravde, Komisija za međunarodno pravo.

Article History:

Received: 15 October 2021

Accepted: 6 December 2021 